\title{
Como matar deus: Caim, de José Saramago
}

\author{
Vanessa Cardoso Brandão \\ (Pontifícia Universidade Católica \\ de Minas Gerais)
}

\begin{abstract}
Caim debate-se com a sua raiva contra o senhor como se estivesse preso nos tentáculos de um polvo, e estas suas vítimas de agora não são mais, como já abel o tinha sido no passado, que outras tentativas para matar deus (SARAMAGO, 2009, p. 169).
\end{abstract}

Caim, que se tornou enfim o último romance da obra do Nobel português, tem um grande projeto: quer levar o leitor, junto a Caim, a matar Deus. Como a personagem de Saramago não pode matar Deus, mata seu irmão Abel e todos na embarcação de Noé - destrói, em última instância, o projeto divino de recomeço da humanidade. Mas não o faz para destruir o homem: no humanismo de Saramago, destruir o divino é mais uma das formas de defender a humanidade, acima de tudo.

A leitura do rico texto de José Saramago parece nos levar a uma questão: simbolicamente, o que significa matar Deus? Para o autor, a morte de Deus é necessária. Sendo o Deus da obra de Saramago um ser inventado pelo próprio homem, o que o texto de Caim pretende mostrar é a face mais humana deste Deus. Um ser cheio de defeitos, como o próprio homem.

O deus de Caim carrega muitas características do de $O$ Evangelho Segundo Jesus Cristo: pode ser amargo e maldoso. É parcial, tem suas preferências, o que se demonstra bem, por exemplo, no ato de receber de braços abertos as ofertas de Abel, recusando as de Caim e gerando um ciúme mortal. Em consequência da injustiça divina, Caim mata o irmão e passa a ser condenado (assim como Adão e Eva já haviam sido). A condenação imposta por Deus é a de que Caim não morra, mas viva em peregrinação.

Novamente, a viagem - temática constante na obra de Saramago torna-se fundamental na narrativa deste romance. A personagem central é condenada a perambular, vagando pelo tempo de forma não-linear e, assim, tornando-se testemunha das ações cruéis de Deus em diversas cenas importantes do antigo testamento. A confusão da Torre de Babel, o sacrifício de Isaac por Abrãao no Monte Sinai, a destruição de Sodoma e Gomorra, a formação da Arca de Noé - estes são alguns dos episódios "invadidos" pelo Caim de Saramago:

Caim mal podia acreditar no que os seus olhos viam. Não bastavam sodoma e gomorra arrasadas pelo fogo, aqui, no sopé do monte sinai, ficara patente a prova 
irrefutável da profunda maldade do senhor, três mil homens mortos só porque ele tinha ficado irritado com a invenção de um suposto rival em figura de bezerro, Eu não fiz mais que matar um irmão e o senhor castigou-me, quero ver agora quem vai castigar o senhor por estas mortes, pensou caim, e logo continuou, Lúcifer sabia bem o que fazia quando se rebelou contra deus, há quem diga que o fez por inveja e não é certo, o que ele conhecia era a maligna natureza o sujeito. (SARAMAGO, 2009, p. 101)

Mais do que apenas assistir à ação do poder divino - em que Deus mostra sua "maligna natureza" ao castigar sem piedade a humanidade Caim quase sempre tem um papel decisivo e entra em cena para intervir no rumo das tão conhecidas histórias bíblicas.

Como ser viajante, a personagem atravessa o tempo, perpassando diversas histórias do Antigo Testamento, desfazendo e relendo mitos bíblicos. Esta desmistificação é uma marca da escrita de José Saramago: em vários outros romances (como o já citado Evangelho Segundo Jesus Cristo, e também A Caverna, História do Cerco de Lisboa, Memorial do Convento) o autor português é conhecido por sua forma de desconstruir mitos e rearranjá-los no contexto ficcional - seja na releitura de textos bíblicos ou históricos. Em Caim, não poderia ser diferente. Essa desmistificação volta-se para a própria imagem de Deus: através da condição errante do protagonista, o autor desvenda ao olhar do leitor a visão de um Deus criador que está longe da imagem que se espera de um ser divino e justo. Não se mostra bondoso e misericordioso, mas vingativo e cruel. Entrega a humanidade a um destino quase sempre marcado pela desgraça: "A história dos homens é a história dos seus desentendimentos com deus, nem ele nos entende a nós, nem nós o entendemos a ele" (SARAMAGO, 2009, p. 88). O Deus de Saramago está, quase sempre, em desentendimento com a humanidade. Assim, o autor mostra a sensação de abandono do homem diante das agruras da vida. Como pode haver um Deus bondoso que permita ainda haver tanta injustiça no mundo? Sabemos da sensação que muitos vivem, ao se deparar com situações difíceis: a de abandono. "Porque Deus fez isso comigo"? Esta é uma questão comum para crentes que, em momentos de dificuldade, começam a duvidar da bondade de Deus. Parece ser esta a pergunta central do romance Caim, de José Saramago. Por trás da pergunta, no entanto, escondem-se outras de maior importância na obra de Saramago: é deus (assim mesmo, em minúscula) realmente responsável pelo destino dos homens? Ou não estaria o homem colocando em um ser (tão inventado como a história de Saramago) muito poder e responsabilidade?

Ao ler o romance, por várias vezes a sensação que temos é a de que Deus não apenas abandona o homem: é ele mesmo o carrasco do homem. É Deus quem entrega o homem aos piores sacrifícios, fazendo de seu destino uma eterna condenação:

Perguntou isaac, Pai, que mal te fiz eu para teres querido matar-me, a mim que sou o teu único filho, Mal não me 
fizeste, isaac, Então porque quiseste cortar-me a garganta como se eu fosse um borrego, perguntou o moço, se não tivesse aparecido aquele homem para segurar-te o braço, que o senhor o cubra de bênçãos, estarias agora a levar um cadáver para casa, $A$ ideia foi do senhor, que queria tirar a prova, A prova de quê, Da minha fé, da minha obediência, E que senhor é esse que ordena a um pai que mate o seu próprio filho, É o senhor que temos, o senhor dos nossos antepassados, o senhor que já cá estava quando nascemos, E se esse senhor tivesse um filho, também o mandaria matar, perguntou isaac, 0 futuro o dirá, Então o senhor é capaz de tudo, do bom, do mau e do pior, Assim é... (SARAMAGO, 2009, p. 8182)

Assim é o Deus de Saramago: capaz do bom, do mau e do pior. Um ser cheio de falhas. Mostrar a face pior do Deus é, então, uma ação política. Afinal, para Saramago, não é Deus (maior ficção da história humana), mas o homem que merece destaque na construção de um novo mundo. Desta forma é que descrer em Deus, sobretudo, significa crer no homem. Na humanidade. Por isso, Saramago coloca em Caim a tarefa dura de matar Deus. Matar Deus para fazer nascer a humanidade.

Tarefa difícil esta da literatura: único lugar onde é possível matar Deus (mesmo que apenas simbolicamente), para fazer aparecer a crença no próprio homem. Como em toda a sua obra, o que Saramago deseja com seu Caim é resgatar a crença na humanidade, no bem que o homem pode protagonizar e, neste sentido, mostrar que há mais bondade no humano do que no divino.

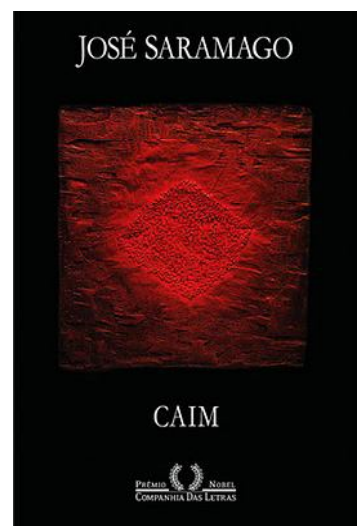

SARAMAGO, José. Caim. São Paulo:

Cia. das Letras, 2009

(Recebido para publicação em 28/05/2010, Aprovado em 21/06/2010) 